\title{
ANALISIS KAPABILITAS TEKNOLOGI INFORMASI TERHADAP KINERJA BISNIS UKM DENGAN ORIENTASI PELANGGAN SEBAGAI VARIABEL INTERVENING (Studi pada UKM Sektor Manufaktur di Wilayah Solo Raya)
}

\author{
Ahmad Sidiq \\ Program Studi Manajemen, STIE Atma Bhakti Surakarta \\ Email:alqodrani@yahoo.com \\ Erni Puji Astutik \\ Program Studi Akuntansi, STIE Atma Bhakti Surakarta
}

Email:erni.puji48@yahoo.com

\begin{abstract}
Abstak
Penelitian ini menguji pengaruh kapabilitas teknologi informasi terhadap kinerja bisnis UKM dengan orientasi pelanggan berperan sebagai mediasi dari hubungan keduanya. Kinerja bisnis UKM yang baik akan memperkuat eksistensi UKM dalam pasar domestik dan meningkatkan kemampuan bersaing secara imbang dalam pasar internasional. Populasi penelitian ini adalah UKM sektor manufaktur di wilayah Solo Raya sebanyak 505 perusahaan dengan sampel 120 UKM. Teknik sampling yang digunakan adalah probability sampling dengan data primer yang bersumber dari pemilik UKM yang mengetahui kondisi penggunaan teknologi informasi dan orientasi pelanggan dalam perusahaan. Metode yang digunakan untuk menganalisa data adalah model persamaan struktural (SEM) dengan bantuan Partial Least Square (PLS). Hasil analisis data menunjukkan kinerja bisnis dapat dijelaskan oleh kapabilitas tehnologi informasi dan orientasi pelanggan sebesar 54\%. Hasil pengujian hipotesis menunjukkan kapabilitas teknologi informasi berpengaruh positif pada orientasi pelanggan dan kinerja bisnis. Selain itu orientasi pelanggan berpengaruh pada kinerja. Adapun orientasi pelanggan dapat berperan sebagai mediasi dalam hubungan antara kapabilitas teknologi informasi dan kinerja bisnis.
\end{abstract}

Kata Kunci : Kapabilitas Teknologi Informasi, Orientasi Pelanggan, Kinerja Bisnis

\section{Abstract}

This study examines the effect of information technology capabilities on the performance of the SME business with customer orientation serves as the mediation of the relationship between information technology capabilities and business performance. SME business performance that will either reinforce the existence of SMEs in the domestic market and increase the ability to compete in balance in the international market. The study population was in the manufacturing sector in the region of Solo Raya as 505 companies with a sample of 120 SMEs. The sampling technique used is the probability sampling with primary data sourced from small business owners who know the conditions of the use of information technology and customer orientation within the company. The method used to analyze the data is structural equation modeling (SEM) with the help of Partial Least Square (PLS). The result showed business performance can be explained by the capabilities of information technology and customer orientation by 54\%. Hypothesis testing results showed the capabilities of information technology has positive effect on customer orientation and business performance. Besides customer orientation effect on performance. The customer orientation can serve as mediating in the relationship between information technology capabilities and business performance.

Key Words: Capability of Information Technology, Customer Orientation, Business Performance 


\section{PENDAHULUAN}

\section{Latar Belakang}

Peran UKM di Indonesia tidak diragukan lagi karena kemampuannya menghadapi krisis ekonomi global. Namun, masih terdapat berbagai halangan yang timbul dan berakibat pada efektivitas dan kinerja mereka. Salah satu halangan penting yang menghambat kesuksesan UKM adalah kelangkaan sumber daya teknologi informasi yang akan berdampak pada kemampuan mereka untuk merespon pasar (Dhungana, 2003; Zhang et al.,2008).

Beberapa penelitian menunjukkan bahwa penggunaan teknologi informasi akan memberi manfaat kepada UKM. Apulu dan Latham (2011) berpendapat bahwa UKM akan memiliki daya saing yang baik apabila dalam menjalankan aktivitas bisnisnya telah mengadopsi TI. Sedangkan Subrahmanya et al.,(2011) juga memiliki pendapat yang serupa bahwa UKM yang memiliki TI akan memiliki kinerja yang jauh lebih baik dibandingkan dengan UKM yang tidak menggunakan TI.

Penelitian Bandi (2006) menunjukkan hasil bahwa teknologi informasi akan berdampak positif bagi perusahaan. Perusahaan akan memiliki kemudahan dalam memasuki pasar, melakukan penganekaragaman jenis produk yang dihasilkan, serta efisiensi biaya produksi. Dampak positif adanya TI pada perusahaan akan mampu meningkatkan kinerja perusahaan pada akhirnya. Jadi dapat dikatakan bahwa pengunaan TI pada perusahaan merupakan langkah strategik yang akan membawa perusahaan pada profitabilitas yang semakin meningkat sehingga yang merupakan salah satu indikator kinerja keuangan.

Arenius et al.,(2006) menyatakan bahwa UKM dapat meningkatkan kinerjanya dengan mengembangkan kemampuan TI lebih besar lagi dan memahani kebutuhan pelanggan sehingga memungkinkan UKM dapat bersaing secara internasional. Walaupun begitu sebagian besar UKM beranggapan bahwa
TI membutuhkan biaya yang relatif tinggidengan kontribusi terhadap kinerja perusahaan yang kurang dapat terukur. Hal ini menyebabkan UKM enggan untuk memanfaatkan TI dalam mendukung aktivitas bisnisnya.

Orientasi pelanggan juga mempengaruhi kinerja bisnis perusahaan dan merupakan salah satu faktor yang dapat meningkatkan keunggulan kompetitif perusahaan. Orientasi pelanggan merupakan suatu komitmen perusahaan pada pelanggannya dengan memahami kebutuhan dan keinginan pelanggan sedemikian rupa sehingga perusahaan mengembangkan suatu strategi yang dapat menciptakan customer value. Perusahaan yang mampu menciptakan customer value akan dapat menumbuhkan loyalitas pelanggan terhadap perusahaan sehingga akan memacu pertumbuhan penjualan perusahaan, kepuasan pelanggan dan pada akhirnya akan meningkatkan kinerja perusahaan.

Penelitian ini mengacu pada penelitian yang dilakukan oleh Nakata et al.,(2008) dan Hsu (2014) yang membuktikan bahwa kemampuan Teknologi Informasi berpengaruh positif terhadap kinerja bisnis suatu perusahaan. Selain itu bukti empiris juga menemukan bahwa orientasi pelanggan merupakan mediasi hubungan antara kemampuan TI dan kinerja bisnis perusahaan. Penelitian yang telah dilakukan Nakata et al.,(2008) dan Hsu (2014) tersebut dilakukan dalam kondisi perekonomian Amerika Serikat dan Taiwan yang memang lebih maju dibandingkan Indonesia. Kondisi perekonomian yang berbeda inilah yang menimbulkan pertanyaan apakah penelitian tersebut juga dapat diterapkan di negara-negara lain khususnya Indonesia, dimana Indonesia memiliki kondisi perekonomian yang jelas sangat berbeda dengan Amerika dan Taiwan. Dengan adanya penelitian ini diharapkan UKM di Indonesia khususnya UKM di Surakarta dapat meningkatkan kemampuan TI yang dimiliki sehingga dapat menyesuaikan dan 
menginovasi secara cepat dan tepat berbagai strategi dalam orientasi pelanggan di lingkungan bisnisnya yang selalu dinamis. Teknologi informasi yang inovatif dan strategi orientasi pelanggan yang tepat merupakan keunggulan kompetitif bagi perusahaan yang akan meningkatkan kinerja UKM. Kinerja UKM yang baik akan berdampak pada meningkatnya daya saing UKM di Indonesia sehingga dapat survive dalam hypercompetitive pasar internasional.

Berdasarkan penjelasan yang disampaikan di atas, maka sangatlah penting untuk melihat pengaruh kapabilitas TI dan orientasi pelanggan dalam meningkatkan kinerja bisnis UKM sehingga UKM diharapkan dapat bersaing dalam pasar internasional. Oleh karena itu, tujuan penelitian ini adalah untuk mengetahui pengaruh kapabilitas teknologi informasi pada orientasi pelanggan dan kinerja bisnis UKM, pengaruh orientasi pelanggan terhadap kinerja bisnis maupun melihat peran orientasi pelanggan sebagai mediasi hubungan antara kapabilitas TI dan kinerja bisnis.

\section{TINJAUAN PUSTAKA \\ Resources Base View (RBV)}

RBV menjelaskan bahwa kinerja perusahaan merupakan perpaduan antara sumber daya berwujud dan tidak berwujud maupun kapabilitas perusahaan. Kedua faktor tersebut akan menjadi kekuatan perusahaan untuk mendapatkan dan mempertahankan keunggulan kompetitifnya. Sumber daya dan kapabilitas menjadi hal yang penting bagi perusahaan apabila sumber daya tersebut mampu meningkatkan efisiensi dan efektifitas dalam kegiatan fungsional perusahaan sehingga memungkinkan untuk melakukan kegiatan yang lebih baik atau lebih murah daripada pesaing. Menurut Stoel dan Muhanna (2009) dalam menghadapi dunia bisnis yang selalu berubah dan penuh dengan tekanan kompetitif dalam berbagai aktivitas inovatif dan imitative maka perusahaan selalu mengembangkan dan memelihara kemampuan apapun termasuk kemampuan IT sehingga perusahaan menjadi lebih unggul dibandingkan pesaing.

\section{Kapabilitas Teknologi Informasi}

Zhang et al.,(2008) mendefinisikan kemampuan teknologi informasi sebagai kemampuan perusahaan untuk memobilisasi dan menyebarkan sumber daya berdasarkan teknologi informasi dalam kombinasi atau penggabungan dengan sumber daya dan kemampuan-kemampuan lain. Adapun Nakata et al., (2008) mendefinisikan kemampuan TI sebagai kemampuan dari suatu sistem komputer, kumpulan komputer dan teknologi terkait dalam sebuah organisasi untuk menyimpan, mengolah, dan menyampaikan informasi. Kemampuan teknologi informasi dipandang sebagai sesuatu yang melekat di dalam proses dan aktivitas rutin perushaaan yang memungkinkan perusahaan tersebut untuk menciptakan nilai dari asetnya (Richardson et al., 2003).

\section{Orientasi Pelanggan}

Orientasi pelanggan menurut Winner (2001) merupakan strategi untuk membangun orientasi yang baik dengan pelanggan dalam jangka panjang dengan mengkombinasikan kemampuan untuk merespon secara langsung dan untuk melayani pelanggan dengan interaksi yang tinggi daripada yang diberikan pesaingnya. Nakata et al.,(2008) menyatakan bahwa customer orientation merupakan syarat utama kesuksesan perusahaan. Perusahaan yang dapat menjaga hubungan baik dengan pelanggan akan memperoleh keunggulan kompetitif karena pelanggan akan terikat dengan perusahaan yang memberikan kepuasan pada mereka (Wirjono, 2003). Perusahaan dengan TI yang handal diharapkan dapat menjalankan strategi customer orientation sehingga hal ini dapat meningkatkan kinerja perusahaan. Oleh sebab itu customer orientation dianggap variabel penting yang akan mempengaruhi 
hubungan kemampuan TI dengan kinerja keuangan perusahaan.

\section{Kinerja Bisnis Perusahaan}

Beberapa peneliti telah berpendapat bahwa kinerja perusahaan harus dilihat dari berbagai multi-dimensi (Nakata et al.,2008; Eskildsen, 2003). Selain itu kinerja keuangan saja kurang memberikan kondisi yang lengkap tentang keadaan perusahaan (Ishtiaque et al., 2007; Khan et al., 2011). Oleh sebab itu dalam mengukur kinerja perusahaan dapat dilihat dari 2 dimensi yaitu dimensi kinerja pasar dan kinerja keuangan. Kinerja pasar mengacu seberapa efektivitasnya suatu perusahaan dalam seluruh aspek pasarnya. Adapun kinerja keuangan mengacu pada efektivitas perusahaaan dalam keuangan yaitu bagaimana perusahaan menghasilkan laba dan return bagi investasinya (Brady dan Cronin, 2001).

\section{PENGEMBANGAN HIPOTESIS Pengaruh kapabilitas teknologi infor- masi terhadap kinerja bisnis perusa- haan}

Orlikowski dan Iacono (2001) menyatakan bahwa TI dapat dikonseptualisasikan sebagai alat untuk mengatur dan memperkuat upaya manusia, terutama dalam informasi tugas. Adapun Nakata et $a l .$, (2008) mendefinisikan kemampuan TI sebagai kemampuan dari suatu sistem komputer, kumpulan komputer dan teknologi terkait dalam sebuah organisasi untuk menyimpan, mengolah, dan menyampaikan informasi. Perusahaan dapat menghabiskan jumlah uang yang sama untuk melakukan investasi teknologi komputer, tetapi akhirnya akan menghasilan kemampuan yang sangat berbeda. Hal ini disebabkan karena harga teknologi informasi yang cepat turun sejalan dengan pengenalan fitur baru, dan beberapa sistem baru untuk merancang dan menggunakan TI tersebut (Kohli dan Devaraj, 2003).

Hsu (2014) dalam penelitian pada perusahaan di Taiwan menunjukkan hasil adanya pengaruh positif signifikan antara strategi TI dengan kinerja organisasi. Strategi TI akan meningkatkan keunggulan kompetitif bagi perusahaan dan akan membantu perusahaan dalam mengefisienkan biaya yang dikeluarkan. Jaferian dan Rezvani (2014) dalam risetnya pada industri manufaktur menyatakan bahwa perusahaan yang memiliki orientasi pada TI akan memiliki kinerja produk yang baik. Berdasarkan uraian teoritis di atas maka hipotesis pertama adalah:

$\mathrm{H}_{1}$ : Semakin tinggi kapabilitas TI maka semakin tinggi kinerja bisnis perusahaan

\section{Pengaruh Kapabilitas TI terhadap Ori- entasi Pelanggan}

Kapabilitas TI merupakan suatu alat yang dapat membantu perusahaan untuk melakukan pengambilan keputusan, pemecahan masalah ataupun melakukan perencanaan. Zhu dan Nakata (2007) melihat bahwa suatu TI yang diaplikasikan oleh perusahaan akan membawa beberapa dampak positif bagi aktivitas bisnisnya. TI dapat mengumpulkan dan mengintegrasikan berbagai data yang dibutuhkan perusahaan dalam memahami masalah yang muncul. Zhu dan Nakata (2007) dalam penelitian melihat bahwa orientasi pelanggan yang dilakukan perusahaan akan berjalan dengan baik apabila difasilitasi dengan kapabilitas TI yang dimilikinya.

Rodriguez et al.,(2014) mengemukakan hasil penelitiannya yang dilakukan pada berbagai jenis industri menunjukkan bahwa teknologi informasi yang digunakan dalam bentuk teknologi media massa maupun sistem customer relationship management (CRM) mampu mempengaruhi kegiatan orientasi pelanggan yang dilakukan perusahaan. Kapabilitas teknologi yang baik pada suatu perusahaan akan membantu perusahaan dalam memahami pelanggan, meningkatkan rasa percaya diri perusahaan dalam beradaptasi menghadapi perubahan kebutuhan pelanggan, mengukur kepuasan pelanggan dan mengharmoniskan aktivitas penjualan dan pemasaran perusahaan dengan pemenuhan 
kebutuhan pelanggan. Berdasarkan uraian tersebut di atas maka hipotesis kedua yang diajukan adalah:

$\mathrm{H}_{2}$ : Semakin tinggi kapabilitas TI maka akan semakin tinggi orientasi pelanggan.

\section{Pengaruh Orientasi Pelanggan terhadap Kinerja Bisnis Perusahaan}

Orientasi pelanggan adalah tingkat kemampuan perusahaan untuk mengidentifikasi, menganalisis, memahami, dan memenuhi kebutuhan pelanggan. Dalam wujud nyata, orientasi pelanggan merupakan sekumpulan informasi aktivitas yang membuat suatu perusahaan secara proaktif memberi perhatian kepada pelanggan maupun pengumpulan, berbagi, dan menanggapi informasi pelanggan (Rindfleisch \& Moorman, 2005; Santhanan \& Hartono, 2003). Nakata et al.,(2008) menegaskan bahwa kepuasan pelanggan merupakan wujud dari perusahaan yang berorientasi pada pelanggan. Perusahaan dengan orientasi pelanggan akan menumbuhkan loyalitas pada perusahaan sehingga pada akhirnya akan meningkatkan kinerja finansial perusahaan.

Beberapa studi menunjukkan orientasi pelanggan secara positif berhubungan dengan pertumbuhan penjualan, laba atas investasi, keberhasilan produk baru, kualitas layanan, dan kinerja karyawan (Brady \& Cronin, 2001). Penelitian yang dilakukan oleh Novello et al.,(2013), Hakala dan Kohtamaki (2010) maupun Tajeddini (2010) menunjukkan hasil adanya pengaruh yang sangat signifikan antara orientasi pelanggan dengan kinerja suatu perusahaan. Demikian pula dengan penelitian Penelitian-penelitian yang dilakukan oleh Farrell et al.,(2009), Mehrabi et al.,(2012), Zebal dan Goodwin (2012) maupun Daud et al., (2013) juga menunjukkan hasil yang sejalan dengan penelitian-penelitian sebelumnya. Berdasarkan uraian teoritis di atas maka hipotesis ketiga adalah:
$\mathrm{H}_{3}$ : Semakin tinggi orientasi pelanggan maka semakin tinggi kinerja bisnis perusahaan

\section{Pengaruh Kapabilitas TI terhadap Kinerja Bisnis dengan Orientasi Pelanggan sebagai Intervening}

Selama ini literatur TI melihat adanya hubungan langsung antara kemampuan TI dengan kinerja perusahaan. Penelitian Santhanam dan Hartono (2003) menemukan bahwa kemampuan TI meningkatkan rasio keuntungan dan biaya bagi perusahaan. Namun sebaliknya dalam penelitian Shin (2001) mengamati bahwa kemampuan TI yang baik tidak meningkatkan return dari investasi dan ekuitas. Sementara itu beberapa literatur mendukung argumen bahwa kemampuan TI akan meningkatkan kinerja keuangan perusahaan. Hal ini menimbulkan dugaan kuat adanya variabel mediasi yang memungkinkan TI akan mempercepat menyelesaikan berbagai tugas dan meningkatkan kinerja perusahaan (Chan,2000; Hu \& Quan,2005).

Hasil penelitian yang dilakukan oleh Nakata et al.,(2008) menunjukkan bahwa kemampuan TI memiliki pengaruh tidak langsung terhadap kinerja bisnis melalui orientasi pelanggan. Hal ini didasarkan bahwa kemampuan TI yang berhubungan positif dengan orientasi pelanggan karena alasan yang berpusat pada informasi pelanggan yaitu pertama, kemampuan TI dapat memfasilitasi pengumpulan sejumlah besar informasi dari pelanggan, contohnya adalah penggunaan internet untuk melakukan survei elektronik atau situs Web untuk memperoleh berbagai data spesifik pelanggan pembeli misalnya demografi, kebiasaan pembelian, produk dan jasa dan tingkat kepuasan (Varadarajan dan Yadav, 2002). Kedua, kemampuan TI dapat membantu dalam berbagi data dengan pelanggan misalnya pertukaran data elektronik (EDI), database yang bersifat terbuka sehingga dapat diakses oleh unit yang terpisah di dalam atau di luar 
perusahaan. Ketiga, kemampuan TI dapat membantu pengambilan keputusan, pemecahan masalah, dan perencanaan berdasarkan informasi pelanggan. Pada akhirnya, kemampuan TI dapat meningkatkan koordinasi dan kecepatan respon di seluruh organisasi untuk memenuhi kebutuhan pembeli. Berdasarkan uraian teoritis di atas maka hipotesis keempat adalah:

$\mathrm{H}_{4}$ : Semakin tinggi kapabilitas TI maka akan semakin tinggi kinerja bisnis perusahaan apabila dimediasi oleh orientasi pelanggan

\section{METODE PENELITIAN}

\section{Populasi dan Pemilihan Sampel}

Populasi penelitian ini adalah Usaha Kecil Menengah (UKM) sektor manufaktur di Surakarta yang terdaftar pada databaseDinas Koperasi dan UMKM Surakarta. Jumlah UKM di wilayah Surakarta sebanyak 505 UKM dengan unit analisis adalah pemilik UKM. Pengambilan sampel penelitian dengan menggunakan metode probability sampling. Jumlah sampel minimal untuk keperluan analisis sebanyak 120 UKM berdasarkan pada pertimbangan jumlah ideal yang diperlukan untuk proses analisis menggunakan PLS adalah 5-10 responden untuk setiap parameter (Ghozali, 2008).

\section{Definisi Operasional dan Pengukuran Variabel Penelitian}

Data dalam penelitian ini adalah data primer yang diperoleh dengan cara observasi, kuesioner dan dokumentasi. Data dari kuesioner akan dilakukan scoring dengan 5 skala likert berkisar antara 'sangat tidak setuju' sampai dengan 'sangat setuju'.

1. Kapabilitas teknologi informasi adalah kemampuan dari suatu sistem komputer, kumpulan komputer dan teknologi lain yang terkait dalam sebuah organisasi untuk menyimpan, mengolah, dan menyampaikan informasi. Pengukuran variabel diadopsi dari penelitian Zhu dan Nakata (2010).

2. Orientasi pelanggan adalah tingkat kemampuan perusahaan untuk mengidentifikasi, menganalisis, memahami, dan memenuhi kebutuhan pelanggan (Gatignon dan Xuereb, 1997). Pengukuran orientasi pelanggan dalam penelitian ini mengadopsi penelitian yang dilakukan oleh Nakata et al.,(2008) maupun Zhu dan Nakata (2010).

3. Kinerja bisnis adalah ukuran seberapa efektif dan efisien perusahaan dalam mencapai tujuan bisnisnya (Nakata et al.,2008). Pengukuran kinerja bisnis perusahaan dalam penelitian ini mengadopsi penelitian yang dilakukan oleh Nakata et al.,(2008) maupun Zhu dan Nakata (2010).

\section{Metode Analisis Data Pengujian Kualitas Data}

Kualitas data dilihat dari hasil pengujian reliabilitas maupun validitas. Pada pengujian reliabilitas akan melihat hasil composite reliability dan Average Variance Extracted (AVE). Sedangkan pengujian validitas akan melihat hasil loading factor yang menunjukkan confergent validity. Menurut Ghozali (2008), suatu konstruk dikatakan reliable apabila memiliki nilai minimal 0.8 untuk composite reliable dan 0.5 untuk AVE. Adapun untuk nilai loading faktor yang diharapkan dapat menunjukkan data yang valid adalah minimal 0.5 .

\section{Pengujian Hipotesis}

Pengujian hipotesis dilakukan dengan Structural Equation Model (SEM) yaitu dengan menggunakan Partial Least Square (PLS). Model struktural dalam penelitian ini dianalisis dengan menggunakan sofware Smart PLS 3. 

adalah :

Adapun persamaan yang dibentuk

$\mathrm{OP}=\beta_{0}+\beta_{1} * \mathrm{KTI}+\varepsilon$

$\mathrm{KB}=\gamma 0+\gamma 1 * \mathrm{OP}+\varepsilon$

Dimana :

$\mathrm{KK}=$ Kinerja Bisnis

KTI = Kapabilitas Teknologi Informasi

$\mathrm{OP}=$ Orientasi Pelanggan

$\varepsilon \quad=$ Error

Pengambilan keputusan pengujian hipotesis didasarkan pada nilai $p$ (probabilitas) dengan nilai signifikansi 0.05 dan membandingkan antara $t$ hitung dan $t$ tabel.

\section{HASIL DAN PEMBAHASAN Deskripsi Responden}

Survey dengan kuesioner pada UKM di wilayah Surakarta menunjukkan hasil bahwa dari 120 kuesioner yang disebar ternyata kuesioner yang kembali sebanyak 97 atau 81\%. Namun dari 97 kuesioner yang kembali hanya 89 buah kuesioner yang dapat digunakan untuk proses analisis pengambilan keputusan dalam uji hipotesis.

Profil responden menggambarkan bahwa dari 89 responden yang berpartisipasi sebagian besar berjenis kelamin laki-laki yaitu sebanyak 72 orang $(81 \%)$, sebagian besar responden berusia di antara 41-50 tahun sebanyak 36 orang (40\%), mayoritas tingkat pendidikan responden adalah Diploma yaitu sebanyak 31 orang (35\%). Sedangkan mayoritas bidang usaha tersebut adalah bidang perdagangan yaitu sebanyak 46 UKM atau sebesar 52\% dengan umur usaha terbanyak adalah 6 10 tahun dan sebanyak 29 UKM atau $33 \%$. Selanjutnya dapat dilihat bahwa sebagian besar responden telah menggunakan teknologi informasi Microsoft Office untuk membantu kelancaran aktivitas bisnis perusahaan dengan tingkat frekuensi penggunaan $4-6$ jam dalam sehari.

\section{Hasil Pengujian Kualitas Data}

Uji kualitas data meliputi reliabilitas dan uji validasi. Nilai suatu konstruk dikatakan reliable jika memberikan nilai composite reliability > 0.60 (Ghozali, 2006). Hasil uji reliabilitas disajikan dalam Tabel 1.

Berdasarkan Tabel 1 composite reliability menunjukkan nilai yang memuaskan yaitu nilai masing-masing variabel di atas nilai minimum yaitu 0.60. Selain itu semuanya variabel memiliki tingkat t statsitik di atas 1,96 atau telah menunjukkan nilai yang signifikan. Berdasarkan hasil analisis tersebut maka nilai tersebut menunjukkan konsistensi dan stabilitas instrumen yang digunakan sangat tinggi. Dengan kata lain dapat disimpulkan bahwa reliabilitas konstruk kapabilitas teknologi informasi, orientasi pelanggan dan kinerja bisnis terpenuhi.

Adapun validitas dinilai dengan validitas konvergen dan validitas diskriminan. Validitas konvergen dilihat dari nilai loading instrumen (besarnya loading faktor untuk masing-masing konstruk). Nilai Loading factor di atas 0.7 sangat direkomendasikan, namun demikian, loading factor antara 0.5 - 0.6 masih dapat ditoleransi sepanjang model masih dalam tahap pengembangan. Tabel 2 menunjukkan dari 18 konstruk yang akan digunakan untuk mengukur model penelitian ternyata seluruh konstruk memiliki nilai loading factor $>0.5$, sehingga disimpulkan bahwa seluruh konstruk dapat digunakan untuk mengukur model penelitian.

Pemenuhan validitas diskriminan dapat diihat dari nilai cross loading konstruk. Jika korelasi indikator konstruk memiliki nilai yang lebih tinggi dibandingkan dengan korelasi indikator tersebut terhadap konstruk lain, maka dapat dikatakan bahwa konstruk memiliki validitas diskriminan yang tinggi (Ghozali, 2006). Cross loading indikator antar konstruk disajikan dalam Tabel 3.

Tabel 3 menunjukkan bahwa konstruk memiliki validitas diskriminan yang sangat tinggi, artinya konstruk laten memprediksi indikator pada blok masingmasing secara lebih baik dibandingkan 
dengan indikator diblok lainnya. Cara lain menguji validitas diskriminan adalah dengan melihat akar dari Average Variance Extracted (AVE), yaitu suatu konstruk dibandingkan dengan nilai korelasi antar konstruk lainnya. Jika nilai akar AVE lebih tinggi daripada korelasi antar konstruk yang lain maka dapat disimpulkan konstruk memiliki tingkat reliabilitas yang baik. Tabel 4 menunjukkan korelasi antara konstruk dengan akar AVE.

Tabel 4 menunjukkan bahwa nilai akar AVE konstruk kapabilitas teknologi informasi, orientasi pelanggan dan kinerja bisnis lebih tinggi dari nilai korelasi antar nilai konstruk lainnya, hal ini mengandung arti bahwa konstruk-konstruk tersebut memiliki valididtas diskriminan yang tinggi.

\section{Hasil Pengujian Model Struktural (Inner Model)}

Pengujian Inner Model dilakukan untuk melihat hubungan antara konstruk dan nilai signifikansinya serta nila $R$ square. Nilai $R$-square digunakan untuk menilai pengaruh variabel independen terhadap variabel dependen apakah memilki pengaruh yang substantif. Tabel 5 menyajikan nilai $\mathrm{R}$-square.

Model memberikan nilai $R$-square sebesar 0.540 pada variabel kinerja bisnis yang berarti bahwa variabel tersebut dapat dijelaskan oleh variabel kapabilitas tehnologi informasi dan orientasi pelanggan sebesar $54 \%$ sedangkan $46 \%$ dapat dijelaskan oleh faktor-faktor lain selain kapabilitas teknologi informasi dan orientasi pelanggan. Sementaara itu variabel orientasi pelanggan dapat dijelaskan oleh variabel kapabalitas teknologi informasi sebesar 0.379 atau $37.9 \%$, selanjutnya orientasi pelanggan dapat dijelaskan oleh faktor-faktor lain selain kapabilitas teknologi informasi sebesar $62.1 \%$

Adapun untuk pengujian hipotesis digunakan metode analisis Partial Least Square (PLS) dengan bantuan program SmartPLS. Hasil pengujian diperoleh model penelitian Gambar 2.

Hasil estimasi dengan menggunakan sampel sebanyak 89, menunjukkan bahwa seluruh hubungan kausalitas yang diuji dalam penelitian ini menunjukkan nilai $t$ statistik yang lebih besar dari 1,96 dengan $p$ value lebih kecil daripada 0.05. Hal ini menunjukkan bahwa seluruh hipotesis yang diajukan dalam penelitian ini diterima. Selanjutnya koefisien estimasi kapabilitas teknologi informasi menunjukkan nilai sebesar 0.368 dan 0.616 yang berarti bahwa setiap kenaikan kapabilitas teknologi informasi sebesar satu satuan akan mengakibatkan naiknya kinerja bisnis sebesar 0.368 satuan dan orientasi pelanggan sebesar 0.616 satuan. Adapun hasil analisis data juga menunjukkan bahwa orientasi pelanggan memiliki koefisien estimasi sebesar 0.448 artinya setiap kenaikan orientasi pelanggan sebesar satu satuan akan menyebabkan naiknya kinerja bisnis sebesar 0.448 satuan. Tabel 6 menunjukkan hasil hubungan antar konstruk atau uji hipotesis penelitian.

Tabel 1. Hasil Uji Reliabilitas

\begin{tabular}{lccc}
\hline \multicolumn{1}{c}{ Konstruk } & Composite Reliability & T-Statistik & P Value \\
\hline Kapabilitas TI & 0.870 & 27.312 & 0.000 \\
Orientasi Pelanggan & 0.885 & 20.905 & 0.000 \\
Kinerja Bisnis & 0.894 & 26.905 & 0.000 \\
\hline
\end{tabular}

Sumber : Data Primer diolah, 2016 
Tabel 2. Hasil Uji Validitas Konvergen

\begin{tabular}{lccc}
\hline & Original sample estimate & Mean of sub samples & T-Statistic \\
\hline Kapabilitas TI & & & \\
- Keahlian & 0.774 & 0.768 & 14.524 \\
- Pengelolaan & 0.781 & 0.775 & 13.443 \\
- Pengembangan & 0.814 & 0.806 & 14.003 \\
- Pengumpulan & 0.676 & 0.674 & 10.736 \\
- Jejaring & 0.720 & 0.712 & 10.467 \\
- Infrastruktur & 0.579 & 0.553 & 4.117 \\
\hline Orientasi & 0.851 & 0.846 & 17.717 \\
Pelanggan & 0.730 & 0.721 & 7.919 \\
- Kepuasan & 0.829 & 0.819 & 13.546 \\
- Pelayanan & 0.824 & 0.821 & 18.490 \\
- Kebutuhan & 0.683 & 0.671 & 7.023 \\
- Kejelasan & 0.553 & 0.524 & 3.737 \\
- Rutinitas & & & \\
- Fokus & & & 3.974 \\
\hline Kinerja Bisnis & 0.550 & 0.540 & 8.654 \\
- Pertumbuhan & 0.705 & 0.696 & 17.603 \\
- Keuntungan & 0.839 & 0.834 & 11.833 \\
- Return & 0.798 & 0.789 & 13.781 \\
- Penjualan & 0.842 & 0.830 & 11.957 \\
- Kualitas & 0.824 & 0.813 & \\
- Penerimaan & & & \\
\hline Sumber: Data Primer & & &
\end{tabular}

Sumber : Data Primer diolah, 2016

Tabel 3. Cross Loading Indikator Antar Konstruk

\begin{tabular}{lccc}
\hline & $\begin{array}{c}\text { Kapabilitas Teknologi } \\
\text { Informasi }\end{array}$ & $\begin{array}{c}\text { Orientasi } \\
\text { Pelanggan }\end{array}$ & Kinerja Bisnis \\
\hline Keahlian & $\mathbf{0 . 7 7 4}$ & 0.432 & 0.465 \\
Pengelolaan & $\mathbf{0 . 7 8 1}$ & 0.521 & 0.513 \\
Pengembangan & $\mathbf{0 . 8 1 4}$ & 0.498 & 0.489 \\
Pengumpulan & $\mathbf{0 . 6 7 6}$ & 0.353 & 0.435 \\
Jejaring & $\mathbf{0 . 7 2 0}$ & 0.460 & 0.566 \\
Infrastruktur & $\mathbf{0 . 5 7 9}$ & 0.406 & 0.303 \\
Kepuasan & 0.523 & $\mathbf{0 . 8 5 1}$ & 0.578 \\
Pelayanan & 0.367 & $\mathbf{0 . 7 3 0}$ & 0.528 \\
Kebutuhan & 0.450 & $\mathbf{0 . 8 2 9}$ & 0.537 \\
Kejelasan & 0.583 & $\mathbf{0 . 8 2 4}$ & 0.583 \\
Rutinitas & 0.498 & $\mathbf{0 . 6 8 3}$ & 0.445 \\
Fokus & 0.297 & $\mathbf{0 . 5 5 3}$ & 0.324 \\
Pertumbuhan & 0.336 & 0.163 & $\mathbf{0 . 5 5 0}$ \\
Keuntungan & 0.417 & 0.510 & $\mathbf{0 . 7 0 5}$ \\
Return & 0.582 & 0.655 & $\mathbf{0 . 8 3 9}$ \\
Penjualan & 0.589 & 0.562 & $\mathbf{0 . 7 9 8}$ \\
Kualitas & 0.483 & 0.538 & $\mathbf{0 . 8 4 2}$ \\
Penerimaan & 0.498 & 0.519 & $\mathbf{0 . 8 2 4}$ \\
\hline
\end{tabular}

Sumber : Data Primer diolah, 2016 
Tabel 4. Korelasi Antara Konstruk dan Akar AVE

\begin{tabular}{lccc}
\hline \multicolumn{1}{c}{ Konstruk } & $\begin{array}{c}\text { Kapabilitas Teknologi } \\
\text { Informasi }\end{array}$ & $\begin{array}{c}\text { Orientasi } \\
\text { Pelanggan }\end{array}$ & $\begin{array}{c}\text { Kinerja } \\
\text { Bisnis }\end{array}$ \\
\hline Kapabilitas Teknologi Informasi & $\mathbf{0 . 7 2 8}$ & & \\
Orientasi Pelanggan & 0.616 & $\mathbf{0 . 7 5 2}$ & \\
Kinerja Bisnis & 0.644 & 0.675 & $\mathbf{0 . 7 6 7}$ \\
\hline
\end{tabular}

Sumber : Data Primer diolah, 2016

Tabel 5. Nilai $R$-square

\begin{tabular}{lc}
\hline Konstruk & R-square \\
\hline Kinerja Bisnis & 0.540 \\
Orientasi Pelanggan & 0.379 \\
\hline \multicolumn{2}{l}{ Sumber : Data Primer diolah, 2010}
\end{tabular}

Tabel 6. Hasil Statistik Inner Model

\begin{tabular}{lccc}
\hline Hubungan Kausalitas Konstruk & Koefisisen Estimasi & t-Statistik & P Value \\
\hline Kapabilitas TI $\rightarrow$ Kinerja Bisnis & 0.368 & 2.326 & 0.020 \\
Orientasi Pelanggan $\rightarrow$ Kinerja Bisnis & 0.448 & 2.633 & 0.009 \\
Kapabilitas TI $\rightarrow$ Orientasi Pelanggan & 0.616 & 6.231 & 0.000 \\
\hline
\end{tabular}

Sumber : Data Primer diolah, 2016

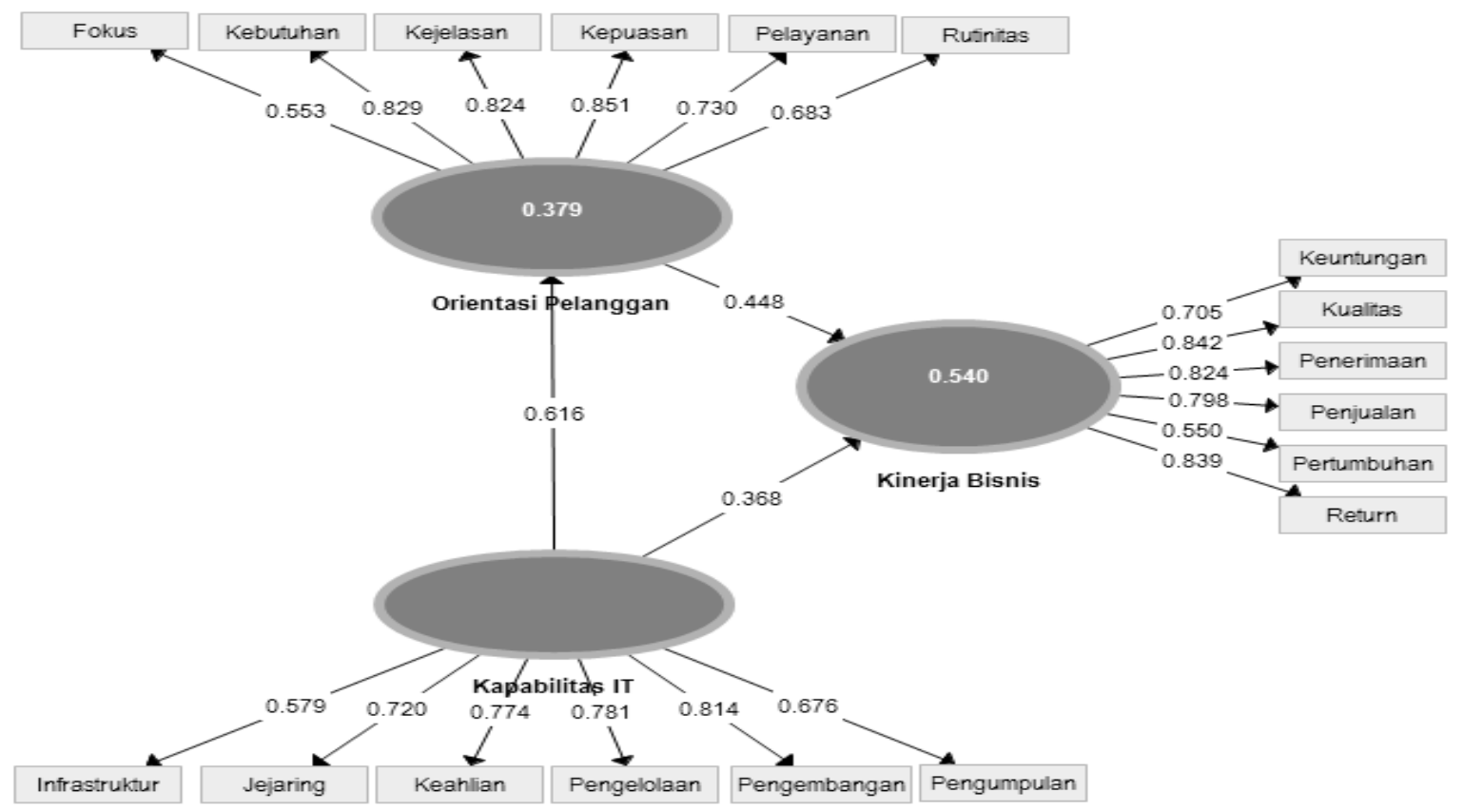

Gambar 2. Full Model Penelitian

Sumber : Hasil analisis data, 2016 


\section{Pengujian Mediasi}

Pengujian efek mediasi dilakukan dengan dua tahap. Tahap pertama melihat besar pengaruh langsung antara konstruk kapabilitas teknologi informasi terhadap kinerja bisnis. Selanjutnya pada tahap kedua akan melihat pengaruh tidak langsung antara konstruk kapabilitas teknologi informasi terhadap kinerja bisnis dengan orientasi pelanggan sebagai konstruk mediasi.

Pada tahap pertama menunjukkan bahwa koefisien estimasi dari pengaruh langsung antara kapabilitasi teknologi informasi terhadap kinerja bisnis adalah sebesar 0.368. Sedangkan pada tahap kedua menunjukkan bahwa pengaruh langsung antara kapabilitas teknologi informasi terhadap orientasi pelanggan adalah sebesar 0.616 dan pengaruh langsung antara orientasi pelanggan terhadap kinerja bisnis adalah sebesar 0.448. Adapun besarnya pengaruh tidak langsung antara kapabilitas teknologi informasi terhadap kinerja bisnis dengan orientasi pelanggan sebagai mediasi sebesar 0.276 ( $0.448 \times 0.616)$.

Menurut Hair et al., (2011) kesimpulan efek mediasi dapat dilihat dari koefisien jalur dari masing-masing kontruk yang ada. Apabila koefisien jalur pengaruh tidak langsung nilainya turun dibandingkan dengan pengaruh langsung namun tetap signifikan maka mengindikasikan adanya bentuk mediasi parsial. Hal tersebut dipenuhi berdasarkan hasil analisis data penelitian ini yang menunjukkan terdapat efek mediasi parsial antara kapabilitas teknologi informasi terhadap kinerja bisnis dengan orientasi pelanggan sebagai variabel mediasi karena nilai pengaruh tidak langsung sebesar 0.276 lebih kecil dari nilai pengaruh langsung yaitu 0.368 .

\section{Hasil Pengujian dan Pembahasan Hipo- tesis}

Pengaruh kapabilitas teknologi infor-
masi terhadap kinerja bisnisperusahaan Kapabilitas teknologi informasi sangat dibutuhkan oleh perusahaan untuk menumbuhkan daya saing dan keunggulan kompetitif jangka panjang perusahaan dalam era pasar bebas dunia. Perusahaan yang memiliki daya saing dan keunggulan kompetitif yang unggul tentunya akan menjadi dasar untuk menciptkan nilai ekonomi dan mencapai kinerja perusahaan yang superior. Kapabilitas teknologi informasi pada dasarnya adalah kemampuan perusahaan dengan teknologi yang dimilikinya mampu mengelola informasi internal maupun eksternal sehingga dapat menjadi sumber daya yang dapat membawa manfaat ekonomis bagi perusahaan. Hal ini sesuai dengan teori Resource Based View dari Barney (1991) yang menyatakan bahwa teknologi informasi merupakan sumber daya perusahaan yang dapat digunakan untuk meningkatkan keunggulan kompetitif bagi perusahaan.

Hasil pengujian statistik terhadap hipotesis 1 menunjukkan nilai koefisien estimasi kapabilitas teknologi informasi terhadap kinerja bisnis perusahaan sebesar sebesar 0.368 dengan $t$ hitung sebesar 2.326 dan $p$ value sebesar 0.020. Nilainilai tersebut telah memenuhi syarat penerimaan hipotesis yaitu t hitung lebih besar dari t tabel sebesar 1,96 pada tingkat signifikansi sebesar 0.05 dan nilai $\mathrm{p}$ value lebih kecil dari probabilitas signifikansi 0.05. Oleh karena itu dapat disimpulkan pengaruh signifikan kapabilitas teknologi informasi terhadap kinerja bisnis perusahaan telah terbukti.

Penelitian ini menyatakan kapabilitas teknologi informasi akan mengarah pada kemampuan perusahaan untuk melakukan kombinasi sumber daya teknologi informasi yang dimilikinya untuk dapat beradaptasi dengan cepat pada perubahan lingkungan bisnis yang dihadapi 
maupun untuk menjaga keberlanjutan keunggulan kompetitif yang dimilikinya. Pongwiritthon dan Noipham (2014) berpendapat bahwa lingkungan kompetitif terjadi karena adanya revolusi teknologi saat ini dan semakin tidak terbendungnya arus globalisasi. Hal ini menjadi dasar bahwa setiap aktivitas bisnis tidak dapat lepas dari adanya teknologi. Teknologi bagaikan darah dan urat nadi yang tidak dapat dipisahkan dari perusahaan. Sedangkan menurut Anand (2013) perusahaan dapat dengan cepat merespon perubahan lingkungan dengan strategi bisnis terbaru. Strategi bisnis akan menjadi efektif bagi perusahaan apabila didukung dengan teknologi informasi yang akurat.

Kapabilitas teknologi informasi pada awalnya akan mempengaruhi kemampuan kerja perusahaan namun pada akhirnya akan membawa dampak positif bagi kinerja perusahaan. Bahkan beberapa penelitian memberi penekanan bahwa keberhasilan jangka panjang suatu perusahaan tidak dapat lepas dari adanya teknologi yang digunakan oleh suatu perusahaan. Hasil penelitian Ali et al.,(2016) di Cina menyatakan adanya kontribusi positif antara kapabilitas teknologi informasi dengan kinerja perusahaan. Perusahaan akan sangat diuntungkan dengan kapabilitas teknologi informasi yang dimilikinya karena dengan teknologi informasi tersebut maka perusahaan akan lebih adaptif menghadapi dinamika lingkungan bisnis. Perusahaan yang memiliki pengetahuan global tentunya akan lebih responsive menghadapi masalah yang dapat mempengaruhi eksistensi perusahaan.

Pada akhirnya dapat dikatakan bahwa penelitian ini konsisten dengan hasil penelitian yang menunjukkan bahwa kemampuan teknologi informasi memiliki dampak yang signifikan terhadap kinerja perusahaan dari Ali et al., (2016), Choi and George (2016); Hsu (2014); Grinstein (2008); Santhanam dan Hartono (2003); dan Bharadjwaj (2000).

\section{Pengaruh Kapabilitas Teknologi Informasi terhadap Orientasi Pelanggan} Perusahaan yang menjalankan bisnisnya dengan menggunakan teknologi informasi sebagai strategi perusahaan akan mampu mengurangi biaya operasional yang timbul dan justru mampu meningkatkan nilai bagi perusahaan. Pertumbuhan pesat dalam penggunaan teknologi informasi mampu memberikan kontribusi terhadap pengetahuan global yang lebih baik dan luas bagi perusahaan sehingga perusahaan mampu melihat peluang bisnis yang menguntungkan bagi perusahaan. Selain itu perusahaan akan lebih mampu memberikan pelayanan terbaiknya untuk pelanggan karena pengetahuan informasi yang lebih cepat dan akurat sehingga menumbuhkan loyalitas pelanggan pada perusahaan.

Hasil pengujian statistik terhadap hipotesis 2 menunjukkan nilai koefisien estimasi kapabilitas teknologi informasi terhadap orientasi pelanggan sebesar 0.616 dengan $\mathrm{t}$ hitung sebesar 6.231 dan $p$ value sebesar 0.000. Nilai-nilai tersebut telah memenuhi syarat penerimaan hipotesis yaitu $\mathrm{t}$ hitung (6.231) lebih besar dari $\mathrm{t}$ tabel $(1,96)$ pada tingkat signifikansi sebesar 0.05 dan $p$ value lebih kecil dari nilai probabilitas sebesar 0.05 . Oleh karena itu dapat disimpulkan pengaruh signifikan kapabilitas teknologi informasi terhadap orientasi pelanggan telah terbukti.

Penelitian Rodriguez et al.,(2014) menunjukkan adanya pengaruh signifikan antara kapabilitas teknologi informasi dan orientasi pelanggan. Customer oriented technology dan sosial media akan memiliki dampak yang sangat baik pada proses orientasi pelanggan. Customer oriented technology akan mengelola informasi dari pelanggan dengan lebih efektif sehingga setiap pengambilan keputusan yang dilakukan oleh perusahaan berkaitan dengan pelanggan akan lebih tepat dan akurat. Customer oriented technology juga akan meningkatkan pemahaman dan adaptasi pada pelanggan. Selain itu perusahaan yang berorientasi pada 
pelanggan akan lebih mudah untuk mengukur tingkat kepuasan pelanggan.

Trainor et al., (2010) dalam penelitiannya mengemukakan bahwa emarketing merupakan salah satu cara untuk menghubungkan perusahaan dengan pelanggan. Pelanggan akan memiliki akses yang mudah mengetahui pemahanan dan dokumentasi produk selain itu akan memudahkan adanya komunikasi elektronik. Hal ini akan memudahkan interaksi atau berbagi pengetahuan pelanggan dengan siklus pengembangan produk perusahaan. Jayachandran et al., (2005) berbagi informasi memainkan peran penting dalam mengembangkan dan mempertahankan hubungan yang kuat antara perusahaan dan pelanggan.

Penelitian ini memiliki konsistensi dengan penelitian-penelitian sebelumnya dari Rodriguez et al.,(2014), Trainor et al.,(2010); Borges et al., (2009), maupun Zhu dan Nakata (2007) yang menunjukkan bahwa kemampuan teknologi informasi memiliki dampak yang signifikan terhadap orientasi pelanggan.

\section{Pengaruh Orientasi Pelanggan terhadap Kinerja Bisnis Perusahaan}

Orientasi pelanggan merupakan ketrampilan yang dimiliki perusahaan untuk memahami dan memuaskan pelanggan. McEachem dan Warnaby (2005) mendefinisikan orientasi pelanggan sebagai elemen orientasi pasar yang mendorong perusahaan untuk menempatkan pelanggan sebagai strategi utamanya atau dapat dikatakan bahwa pelanggan sebagai jantung dari perusahaan dan kehidupan perusahaan ditentukan dari keberadaan pelanggan. Orientasi pelanggan akan menjadi dasar bagi perusahaan untuk memahami pasar bisnisnya sehingga mampu mengembangkan strategi produk dan layanannya untuk memenuhi kebutuhan dan tuntutan pelanggannya. Oleh karena itu orientasi pelanggan memiliki peran penting dalam aktivitas perusahaan dan menciptakan perilaku yang cukup krusial dalam meningkatkan kinerja maupun eksistensi perusahaan.

Hasil pengujian statistik terhadap hipotesis 3 menunjukkan nilai koefisien estimasi orientasi pelanggan terhadap kinerja bisnis perusahaan sebesar 0.448 dengan t hitung sebesar 2.633 dengan nilai $\mathrm{p}$ value sebesar 0.009. Nilai-nilai tersebut telah memenuhi syarat penerimaan hipotesis yaitu $\mathrm{t}$ hitung lebih besar dari $\mathrm{t}$ tabel sebesar 1,96 pada tingkat signifikansi sebesar 0,05 dan nilai probabilitas lebih kecil daripada 0.05. Oleh karena itu dapat disimpulkan bahwa pengaruh signifikan orientasi pelanggan terhadap kinerja bisnis perusahaan telah terbukti.

Beberapa penelitian telah menunjukkan temuan adanya hubungan yang signifikan antara orientasi pelanggan dan kinerja perusahaan antara lain penelitian dari Ali et al.,(2016), Pongwiritthon dan Noiphan (2014), Mehrabi et al.,(2012) dan Asikhia (2010). Ali et al.,(2016) berpendapat bahwa perusahaan-perusahaan skala besar yang memiliki orientasi pada pelanggan justru akan memiliki pengaruh yang positif pada kinerjanya karena keuntungan yang diperoleh dari interaksi dengan pelanggan mampu meningkatkan profit yang diperoleh perusahaan. Pongwiritthon dan Noiphan (2014) juga mengemukakan hasil penelitiannya yaitu orientasi pelanggan merupakan strategi untuk bertahan hidup bagi perusahaan yang diwujudkan dalam berbagai aktivitas eksplisityang dapat dirasakan oleh pelanggan sehingga pelanggan akan memberikan dukungan penuh pada perusahaan yang mampu memenuhi kebutuhannya. Hal ini dapat menjadi dasar bagi pertumbuhan penjualan dan kinerja suatu perusahaan.

Menurut Mehrabi et al.,(2012), perusahaan yang memberi penekanan pada produk dan layanan bagi pelanggan akan membantu perusahaan meningkatkan keunggulan kompetitifnya. Perusahaan akan meningkatkan manfaat yang diberikan pada pelanggan atau akan mengurangi biaya bagi pelanggan sehingga 
akan meningkatkan respon positif pelanggan pada perusahaan melalui kepuasan maupun loyalitas pada produk atau layanan perusahaan. Oleh karena itu dapat dipahami bahwa orientasi pelanggan perusahaan memiliki dampak positif pada kinerja bisnis perusahaan.

\section{Pengaruh Kapabilitas Teknologi Informasi terhadap Kinerja Bisnis dengan Orientasi Pelanggan sebagai Intervening}

Pelanggan merupakan pondasi dalam bisnis perusahaan oleh karena itu perusahaan senantiasa menjaga hubungan baik dengan pelanggan. Perusahaan harus mampu memahami berbagai hal yang dibutuhkan atau diinginkan oleh pelanggan sehingga pelanggan tidak akan berpindah haluan ke pesaing namun justru memberi nilai ekonomis dan meningkatkan kinerja perusahaan. Untuk dapat memahami berbagai kebutuhan dan keingginan pelanggan maka perusahaan harus memiliki informasi yang akurat akan hal tersebut. Informasi akan memiliki sifat akurat apabila didukung dengan teknologi yang baik. Sehingga pada akhirnya dapat dikatakan bahwa kemampuan teknologi informasi dapat menjadi anteseden bagi perusahaan yang berorientasi pada pelanggan untuk meningkatkan kinerjanya.

Hasil pengujian statistik terhadap hipotesis 4 menunjukkan nilai koefisien estimasi pengaruh langsung kapabilitas teknologi informasi terhadap kinerja bisnis perusahaan sebesar sebesar 0.368 dengan $t$ statistik sebesar 2.326 yang menunjukkan signifikansi pada 0.05. Sedangkan koefisien estimasi pengaruh kapabilitas teknologi informasi pada kinerja bisnis dengan orientasi pelanggan sebagai mediasi adalah sebesar 0.276 dengan $t$ hitung sebesar 2.186 yang menunjukkan signifikansi pada 0.05. Oleh karena itu dapat disimpulkan bahwa orientasi pelanggan dapat berperan sebagai mediasi dalam hubungan antara kapabilitas teknologi informasi terhadap kinerja bisnis perusahaan. Oleh karena itu hasil analisis memberi dukungan bahwa hipotesis ke empat terbukti.

Hasil penelitian ini sesuai dengan penelitian Haisley (2004) yang menyatakan bahwa kemampuan teknologi informasi memiliki hubungan positif dengan kinerja bisnis melalui orientasi pelanggan dengan dasar pemahaman bahwa pemanfaatan teknologi informasi memungkinkan perusahaan untuk bekerja lebih efisien dalam merespon kebutuhan pelanggan sehingga perusahaan akan lebih mudah menterjemahkan harapan pelanggan dan menyelaraskan aktivitas bisnis perusahaan dengan harapan pelanggan tersebut.

Hasil penelitian Nakata et al.,(2008) juga konsisten dengan hasil penelitian ini yaitu menunjukkan adanya pengaruh kemampuan teknologi informasi terhadap kinerja bisnis melalui orientasi pelanggan sebagai intervening. Kemampuan teknologi informasiakan menghimpun berbagai informasi penting mengenai pelanggan sehingga akan membantu perusahaan dalam pengambilan keputusan, pemecahan masalah atau perencaaan kegiatan perusahaan dalam rangka pemenuhan kebutuhan pelanggan. Hal inilah yang pada akhirnya akan membuat kemampuan teknologi informasi dapat meningkatkan koordinasi dan kecepatan respon di seluruh organisasi untuk memenuhi kebutuhan pelanggan sehingga keunggulan kompetitif dan kinerja perusahaan dapat dipertahankan atau bahkan ditingkatkan. Demikian juga Roberts dan Grover (2012) dalam penelitian menyebutkan bahwa kapabilitas teknologi informasi akan membantu perusahaan merespon dengan cepat peluang bisnis yang ditawarkan oleh pelanggan untuk inovasi dan meningkatkan keunggulan kompetitif. 


\section{PENUTUP}

\section{Kesimpulan}

1. Kapabilitas teknologi informasi berpengaruh positif terhadap kinerja bisnis. Hasil penelitian ini konsisten dengan penelitian yang telah dilakukan oleh Ali et al.,(2016), Choi and George (2016); Hsu (2014); Grinstein (2008); Santhanam dan Hartono (2003); dan Bharadjwaj (2000). Keunggulan kompetitif dan kinerja perusahaan dapat dipertahankan atau bahkan ditingkakan dengan kapabilitas teknologi informasi yang dimiliki perusahaan. Kapabilitas teknologi informasi bagaikan urat nadi perusahaan akan meningkatkan kemampuan perusahaan beradaptasi dengan dinamika lingkungan bisnis dalam arus globalisasi. Kapabilitas teknologi informasi akan memberikan pengetahuan global bagi perusahaan untuk lebih responsive dalam menghadapi masalah yang memepengaruhi eksistensi perusahaan.

2. Kapabilitas teknologi informasi berpengaruh positif terhadap orientasi pelanggan. Hasil penelitian ini konsisten dengan penelitian yang dilakukan oleh Rodriguez et al.,(2014), Trainor et al.,(2010); Borges et al.,(2009), maupun Zhu dan Nakata (2007). Kapabilitas teknologi informasi mampu meningkatkan nilai perusahaan melalui peluang bisnis yang dapat ditangkap oleh perusahaan karena interaksinya dengan pelanggan. Customer oriented technology akan mengelola informasi pelanggan dengan efektif sehingga perusahaan akan mampu melakukan pengambilan keputusan dengan tepat dan benar. Kapabilitas teknologi informasi melalui e-marketing akan memudahkan pelanggan dan perusahaan berinteraksi dan berbagi informasi. Oleh karena itu dapat dikatakan bahwa perusahaan yang memiliki kapabilitas teknologi informasi yang baik akan mampu mengembangkan dan mempertahankan hubungannya dengan pelanggan sehingga ekspektasi pelang- gan terhadap perusahaan mampu diwujudkan.

3. Orientasi pelanggan berpengaruh positif terhadap kinerja bisnis. Hasil penelitian ini konsisten dengan penelitianyang telah dilakukan oleh Ali et al.,(2016), Pongwiritthon dan Noiphan (2014), Mehrabi et al.,(2012) dan Asikhia (2010). Perusahaan yang berorientasi pada pelanggan akan memiliki kemampuan untuk memahami dan memuaskan pelanggan. Orientasi pelanggan sebagai driver bagi perusahaan untuk memahami pasar bisnisnya sehingga mampu mengembangkan strategi produk dan layanannya untuk memberikan kepuasan pada pelanggan. Oleh karena itu orientasi pelanggan berperan penting dalam aktivitas perusahaan dan menciptakan perilaku yang sangat krusial dalam meningkatkan kinerja perusahaan.

4. Pengaruh kapabilitas teknologi informasi terhadap kinerja bisnis dengan orientasi pelanggan sebagai intervening. Hasil penelitian ini konsisten dengan penelitian yang telah dilakukan oleh Roberts dan Grover (2012), Nakata et al., (2008), dan Haisley (2004). Pemanfaatan teknologi informasi akan lebih mendorong perusahaan untuk bekerja dengan lebih efisien, sehingga perusahaan dapat lebih mudah menangkap informasi-informasi penting dari pelanggan dan menterjemahkannya menjadi produk atau layanan yang diharapkan oleh pelanggan. Dengan kata lain bahwa kapabilitas teknologi informasi akan meningkatkan koordinasi dan kecepatan respon dalam perusahaan untuk memenuhi kebutuhan pelanggan sehingga keunggulan kompetitif dan kinerja perusahaan dapat dipertahankan atau ditingkatkan.

\section{Saran}

1. Jumlah sampel UKM hendaknya diperbanyak sehingga akan meningkatkan kemampuan generalisasi dari hasil penelitian ini. 
2. Perlu upaya untuk mengembangkan dan memperdalam teori khususnya yang berkaitan dengan kapabilitas teknologi informasi, orientasi pelanggan dan kinerja bisnis maka penelitian yang akan datang dapat dilakukan pada perusahaan dengan skala besar.

3. Pilot studi dapat dilakukan oleh peneliti di masa akan datang karena responden di sektor UKM memiliki pemahaman yang minim dalam mencermati pertanyaan yang diajukan dalam kuesioner. Hal ini bisa saja menyebabkan hasil penelitian kurang akurat.

\section{DAFTAR PUSTAKA}

Ali, R., Leifu, G., \& Rehman, R. (2016). The Impact Of Technology Orientation And Customer Orientation On Firm Performance: Evidence Form Chinese Firms, International Journal of Management and Marketing Research, 9(1), 1-11.

Anand, A. (2013). The effect of IT capabilities on firm performanceevidance from the healthcare industry. University of Wollongong Thesis Collection. School of Information Systems and Technology Faculty of Informatics. Australia.

Apulu, I., \& Latham, A., (2011). Drivers for information and communication technology adoption: A case study of Nigerian small and medium sized enterprises. International Journal of Business and Management, 6(5), 5160.

Arenius, P., Sasi, V., \& Gabrielsson, M. (2006). Rapid internationalization enabled by the Internet: the case of a knowledge intensive company. Journal of International Enterprise, 3(4), 279-290.
Asikhia, O. (2010). Customer Orientation and Firm Performance among Nigerian Small and Medium Scale Businesses. International Journal of Marketing Studies, 2(1), 197-212.

Bandi. (2006). Pengaruh respon perusahaan dalam investasi teknologi informasi terhadap kinerja perusahaan: strategi bisnis, kematangan teknologi informasi, dan ukuran perusahaan sebagai variabel anteseden. Simposiun Nasional Akuntansi IX. Padang.

Barney, J.B. (1991). Firm Resources and Sustained Competitive Advantage (PDF). Journal of Management, 17(1), 99-120.

Bharadwaj, A.S. (2000). A resource-based perspective on information technology capability and firm performance: an empirical investigation. MIS Quarterly, 24, 169-196.

Borges, M., Hoppen, N., \& Luce, F.B. (2009). Information technology impact on market orientation in ebusiness. Journal of Business Research,62(9), 883-890.

Brady, M. K. \& Cronin, J. J. (2001). Customer Orientation: Effects on Customer Service Perceptions and Outcome Behaviors. Journal of Service Research, 3(3), 241-251.

Chan, Y. E. (2000). IT Value: The Great Divide Between Qualitative and Quantitative and Individual and Organizational Measures. Journal of Management Information Systems, 16(4), 225-261. 
Choi, I., \& George, J.F. (2016). Mixed Findings on IT Capability and Firm Performance and their Implications. Twenty-second Americas Conference on Information Systems, San Diego.

Daud, W.N.W., Remli, N., \& Muhammad H. (2013). Market Orientation and Performance: A Study of Takaful Performance in Malaysia. Asian Social Science, 9(4), 240-247.

Dhungana, B.P. (2003). Strengthening the competitiveness of Small and Medium Enterprises in the globalization process: prospects and challenges. Investment Promotion and Enterprise Development Bulletin for Asia and the Pacific No. 1, (ESCAP). United Nations Publications, New York, NY, USA. http://www.unescap.org/tid/project/tf arm03_inst.pdf. Diakses pada 21 Desember 2014.

Eskildsen, J. (2003). The Predictive Power of Intangibles. Measuring Business Excellence, 7(2), 46-50.

Farrell, M., Oczkowski, E., \& Kharabsheh, R. (2008). Market orientation, learning orientation and organisational performance in international joint ventures. Asia Pacific Journal of Marketing and Logistics, 20(3), 289-308.

Gatignon, H., \& Xuereb, J. M. (1997). Strategic Orientation in the Firm and New Product Performance. Journal of Marketing Research, 34(1), 77-90.

Ghozali, I,. 2008. Structural Equation Modeling: Metode alternatif dengan partial least square. Edisi kedua. Semarang: Badan Penerbit Universitas Diponegoro.
Grinstein, A. 2008. The relationships between market orientation and alternative strategic orientations: A meta-analysis. European Journal of Marketing, 42(1/2), 115-134.

Hair, J. F., Ringle, C.M., \& Sarstedt, M. (2011). PLS-SEM: Indeed a Silver Bullet. Journal of Marketing Theory and Practice, 19(2), 139-151.

Hakala, H., \& Kohtamaki, M. (2010). The Interplay Between Orientations: Entrepreneurial, Technology And Customer Orientations In Software Companies. Journal Enterprising Culture, 18(03), 265-290.

Hanafi, M.M., \& Halim, A. (2005). Analisis Laporan Keuangan. Edisi Kedua. Yogyakarta: UPP AMP YKPN.

Haisley, T. (2004). Software Implementation Series, Part I: Northern Retail Group Overhauls IT Infrastructure. Apparel. 45(9), 58-60.

Hu, Q. \& Quan, J. J. (2005). Evaluating the Impact of IT Investments on Productivity: A Causal Analysis at Industry Level. International Journal of Information Management, 25(1), 39-53.

Hsu, S. (2014). Effects of Organization Culture, Organizational Learning and IT Strategy on Knowledge Management and Performance. The Journal of International Management Studies, 9(1), 50-58.

Ishtiaque, A.A., Khan, H., Akter, S., \& Fatima, Z.K. (2007). Perception Analysis of Balanced Scorecard: An Application Over a Multinational Corporation of Bangladesh. Journal Business Study, 28(2), 238-268. 
Jaferian, S., \& Rezvani, M. (2014). Export New Product Success: The Impact of Market and Technology Orientation. International Journal of Management. Accounting and Economics, 1(5), 322-337.

Jayachandran, S., Sharma, S., Kaufman, P., \& Raman, P. (2005). The role of relational information processes and technology use in customer relationship management. Journal of Marketing, 69(4), 177-192.

Khan, R. A. G., Khan, F. A., \& Khan, M. A. (2011). Impact of Training and Development on Organizational Performance. Global Journal of Management and Business Research, 11(7).

Kohli, R., \& Devaraj, S. (2003). Measuring Information Technology Payoff: A Meta-analysis of Structural Variables in Firm-level Empirical Research. Information Systems Research, 14(2), 127-145.

Levin, A. (2000). Decision Support Tech Saves Insurers Time. National Under-writer, 104, 23(3).

Orlikowski, W.J., \& Iacono, C.S. (2001). Desperately Seeking The "IT" In IT Research - a Call to Theorizing the IT Artifact. Information Systems Research, 12(2), 121-134.

Pongwiritthon, R. \& Noiphan, R. (2014). Customer Orientation and Firm Performance among SMEs in Thailand. Suranaree Journal Social Science, 8(1), 73-93.

Mc Eachern, M., \& Warranty, G. (2005). Improving customer orientation within the fresh meat supply Chain. Journal of Marketing Management, $21(1 / 2), 89-115$.
Mehrabi, J., Noorbakhash, K., Shoja, M., \& Karim, M. (2012). Impact of Customer Orientation and Sales Orientation on Sales Performance in International Market of Bilehsavar Country. International Journal of Business and Social Science, 3(17), 216-222.

Nakata, C., Zhu, Z., \& Kraimer, M.L. (2008). The Complex Contribution of Information Technology Capability to Business Performance. Journal of Managerial Issues, 20(4), 485-506.

Novello, S., Lengler, J., \& Fernandez, F.M., (2013). Customer Orientation and SME export performance: Insights from Italian manufacturing firms. Micro \& Macro Marketing, 12(3), 453-470.

Richardson, V.J., Subramani, M., \& Zmud R.W. (2003). Benefiting from Information Technology Investments: the Role of IT Conversion Capability. Second Round Review at MIS Quarterly.

Rindfleisch, A. \& Moorman, C. (2005). Interfirm Cooperation and Customer Orientation. Journal of Marketing Research, 40(4), 421-436.

Roberts, R., \& Grover. (2012). Leveraging Information Technology Infrastructure to Facilitate a Firm's Customer Agility and Competitive Activity: An Empirical Investigation. Journal of Management Information Systems, 28(4), 231-270.

Rodriguez, M., Ajjan, H., \& Peterson, R.M. (2014). CRM/Social Media Technology: Impact on Customer Orientation Process and Organizational Sales Performance. Journal of Marketing Development and Competitiveness, 8(1), 85-97. 
Santhanam, R. \& Hartono, E. (2003). Issues in Linking Information Technology Capability in Firm Performance. MIS Quarterly. 27(1), 125-153.

Shin, N. (2001). The Impact of Information Technology on Financial Performance: The Importance of Strategic Choice. European Journal of Information Systems, 10(4), 227236.

Stoel, M. D., \& Muhanna, W. A. (2009). IT Capabilities and Firm Performance: A Contingency Analysis of the Role of Industry and IT Capability type. Information and Management, 46(3), 181-189.

Subrahmanya, M. H. B., Mathirajan, M., \& Krishnaswamy, K. N. (2011). Importance of technological innovation for SME growth: Evidence from India. World Institute for Development Economics Research, 3.

Tajeddini, K. (2010), Effect of customer orientation and entrepreneurial orientation on innovativeness: Evidence from the hotel industry in Switzerland. Tourism Management, 31(2), 221-231.

Trainor, K. J., Rapp, A., Beitelspacher, L. S., \& Schillewaert, N. (2010). Integrating information technology and marketing: An examination of the drivers and outcomes of eMarketing capability. Industrial Marketing Management, 40(1), 162174.

Winner, G. (2001). Marketing Planning And Strategy. $5^{\text {th }}$ Ed. South-Western: College Publishing
Wirjono, E.R. (2003). Perwujudan customer orientation melalui perubahan sistem akuntansi manajemen dalam institusi jasa keuangan. Kinerja. 7(1), 49-56.

Varadarajan, P. R., \& Yadav, M. S. (2002). Marketing Strategy and the Internet: An Organizing Framework. Journal of the Academy of Marketing Science, 30(4), 296-312.

Zebal, M. A., \& Goodwin, D. R., (2012), Market orientation and performance in private universities. Marketing Intelligence \& Planning, 30(3), 339357.

Zhang, M., Sarker, S., \& Sarker, S. (2008). Unpacking the effect of IT capability on the performance of exportfocused SMEs: a report from China. Information System Journal, 18(4), 357-380.

Zhu, Zhen., \& Nakata, C. (2007). Reexamining The Link Between Customer Orientation And Business Performance: The Role Of Information Systems. Journal of Marketing Theory and Practice, 15(3), 187. 